\title{
Resuspension of postlarval soft-shell clams Mya arenaria through disturbance by the mud snail Ilyanassa obsoleta
}

\author{
Robert Dunn*, Lauren S. Mullineaux**, Susan W. Mills \\ Biology Department, Woods Hole Oceanographic Institution, Woods Hole, Massachusetts 02543, USA
}

\begin{abstract}
Transport and mortality of newly settled post larvae potentially have a large influence on the population dynamics and adult distributions of coastal benthic species, including the soft-shell clam Mya arenaria. Post-settlement transport typically occurs when boundary shear stresses are high enough to resuspend the surface sediments in which the small clams reside. The objective of the present study was to examine the effect of disturbance by the mud snail Ilyanassa obsoleta on the hydrodynamic transport of recently settled $M$. arenaria. Laboratory flume experiments showed that disturbance by activities of $I$. obsoleta caused suspension of small clams (1.8 and $2.3 \mathrm{~mm}$ ) at boundary shear velocities (1.0 and $\left.1.3 \mathrm{~cm} \mathrm{~s}^{-1}\right)$ that were too slow to suspend undisturbed clams. In shear velocities high enough to cause bulk sediment transport $\left(1.4\right.$ and $\left.2.0 \mathrm{~cm} \mathrm{~s}^{-1}\right)$, more clams were suspended in the presence of snails than in their absence. Manipulative field experiments using cages to exclude snails demonstrated that abundances of juvenile $M$ arenaria (year-1 recruits) were lower in sediments where snails were present than where snails were absent. These results suggest that biological disturbance, such as that imposed by activities of mobile, benthic deposit feeders, may play an important role in postlarval transport and, eventually, in the adult distributions of infaunal bivalves.
\end{abstract}

KEY WORDS: Postlarval transport - Mya arenaria - Soft-shell clam - llyanassa obsoleta - Disturbance Boundary shear stress - Caging experiments

\section{INTRODUCTION}

Historically, most studies of species composition and population dynamics of benthic ecosystems have focused primarily on adult organisms. More recently, efforts to understand the variability in recruitment of marine benthic organisms have included investigation of processes influencing the patterns of settlement of their planktonic larval stages (e.g. reviews by Butman 1987, Rodriguez et al, 1993). However, many sediment-dwelling infaunal organisms continue to move as juveniles (Palmer 1988, Emerson \& Grant 1991). Larvae are influenced by water-column conditions, cur-

- Present address: Dept. of Ecology \& Evolutionary Biology, U-43 University of Connecticut, Storrs, Connecticut 062693042, USA

- Addressee for correspondence.

E-mail:1mullineaux@whoi.edu rents, and benthic conditions while settling, and these factors have been used to predict settlement patterns (e.g. Eckman 1990). The location and density of juveniles, however, may be influenced by post-settlement transport and mortality over weeks to months (Beukema \& de Vlas 1989, Commito et al. 1995, Armonies 1996). As a result, when rates of transport of juveniles are high, the larval settlement patterns may bear little resemblance to adult distributions.

The soft-shell clam Mya arenaria (L.) is subject to post-settlement transport, as reported in both field (Emerson \& Grant 1991) and laboratory (Roegner et al. 1995) studies. This transport may contribute to the high temporal and spatial variation in recruitment observed in many populations (e.g. Möller \& Rosenberg 1983). Suspension of juveniles and their subsequent translocation is due to boundary shear stress on the clams and the surrounding sediments. Susceptibility of juvenile clams to resuspension can be influenced by their be- 
havior. Clams can facilitate suspension by extending their byssal fibers (Sigurdsson et al. 1976) or by migrating to the surface. They can make suspension less likely by attaching to the substrate with their byssal fibers (Newell \& Hidu 1986) or burrowing deeply (as demonstrated for meiofauna by Palmer 1984, Fegley 1987). The depth to which clams can burrow, however, is limited by the length of their siphon, and therefore their size (Peterson 1985, Zwarts \& Wanink 1989). Thus, small clams are restricted to the upper layer of sediment, making them the most susceptible to resuspension. Suspension also may be facilitated through local disturbance by benthic organisms and fish, as well as by more-intensive anthropogenic disturbances (i.e. Brown \& Wilson 1997).

The mud snail Ilyanassa obsoleta (Say) occurs commonly in high densities and may be an important disturber of soft-shell clams. This snail feeds on surface sediments and carrion (Feller 1984) and is common in intertidal flats and shallow subtidal areas on both coasts of the continental USA. It has been shown to reduce the abundance of the nematode Pseudotheristid nematodes (Nichols \& Robertson 1979), and bivalves and other organisms (Hunt et al. 1987), and induce migration of the amphipod Microdeutopus gryllotalpa (DeWitt \& Levinton 1985) and the snail Hydrobia totteni (Levinton et al. 1985). In the presence of $I$. obsoleta, the larger species such as M. gryllotalpa and $H$. totteni emigrate actively, but the mechanism by which $I$. obsoleta excludes smaller infaunal species remains unclear.

Our objective in the present study was to examine the role of the mud snail in the disturbance and subsequent suspension of postlarval soft-shell clams. We used laboratory flume experiments to determine whether snails affect the boundary shear stress at which clams are suspended and the proportion of clams suspended in a particular flow environment These experiments were intended to provide the ability to predict the range of boundary shear stresses in which snails may have an effect, and to estimate the probable magnitude of the effect. We then used manipulative field experiments to determine whether the presence or absence of snails affected suspension and transport of postlarval clams in field flows.

\section{MATERIALS AND METHODS}

Flume experiments. All flume experiments were conducted in a $17 \mathrm{~m}$ long, $60 \mathrm{~cm}$ wide, steady re-circulating flume located in the Rinehart Coastal Research Center (RCRC) at Woods Hole Oceanographic Institution (Butman \& Chapman 1995). The flume was equipped with an impeller pump and a 2-axis Laser
Doppler Velocimeter (LDV) that provided simultaneous along-stream and vertical velocity measurements (described in Trowbridge et al. 1989). The water height was set at $12 \mathrm{~cm}$ during each trial run, and 4 min velocity averages were measured at 10 heights over the center of the channel. Calculations of boundary shear velocity $(u$.$) were made from the resulting velocity$ profile using the log profile technique (e.g. Jumars \& Nowell 1984). Specific flows were replicated by using the same pump speed and outlet weir setting. For all treatments, a removable bottom panel of the flume was fitted with a sediment tray. The tray was a clear acrylic sheet with a recessed $20 \times 20 \times 2 \mathrm{~cm}$ deep central box to hold sediment.

Experiments were conducted with 2 different sizes of clams: the smaller group had a mean length of $1.8 \mathrm{~mm}$ ( $\mathrm{SD}=0.15 \mathrm{~mm} ; \mathrm{n}=100$ ), corresponding in size to juvenile Mya arenaria midway through their first summer season in Barnstable Harbor ( 1 to $2 \mathrm{~mm}$; as estimated from field data not shown) and the larger had a mean length of $2.3 \mathrm{~mm}(\mathrm{SD}=0.30 \mathrm{~mm} ; \mathrm{n}=100)$, corresponding late-season juveniles in the field $(2$ to $3 \mathrm{~mm}$ in length). The larger juveniles were acquired from Beals Island Shellfish Hatchery, Beals, Maine, USA, where they had been hatched on May 21, 1997. We conducted experiments with these clams from July 22 to 23. A second group of smaller clams spawned on July 8 at Mook Sea Farm, Walpole, Maine, was used in experiments from August 13 to 21. All clams were maintained in plastic containers covered with $64 \mu \mathrm{m}$ mesh and supplied with running seawater. The clams were fed Isochrysis galbana algae at least once a day and kept at approximately $21^{\circ} \mathrm{C}$.

Sediment for all trials was collected in Barnstable Harbor, Massachusetts, USA; it was sieved through a $2 \mathrm{~mm}$ sieve to remove the largest fraction and retained on a $180 \mu \mathrm{m}$ sieve to remove the smallest size fraction. The large size fraction was removed to eliminate large pieces of shell and other material that might cause small-scale variation in boundary shear stress. The smallest fraction was removed to make the distributions of grain size more consistent from run to run because there was spatial variability in the amount of very fine sediment and flocculent material within field collection sites. The median grain size of the processed sediment was in the 150 to $180 \mu \mathrm{m}$ range. For each trial, the tray was filled with well-mixed sediment and evened off so that the sediment surface was flush with the surface of the tray. Adult snails (Ilyanassa obsoleta) roughly 1.2 to $2.0 \mathrm{~cm}$ in length were collected from our Thatch Island site (northwest region of Little Thatch Island) in Barnstable Harbor, and maintained for 2 to $4 \mathrm{~d}$ in plastic containers filled with a layer of sediment. The container was kept in an unfiltered, aerated running seawater table. 
Clams were introduced into the sediment tray while it was submerged in a running seawater table through a clear acrylic cylinder $(10 \mathrm{~cm}$ diameter, $20 \mathrm{~cm}$ high) held approximately $1 \mathrm{~cm}$ above the sediment. The cylinder was used to distribute the clams evenly on the sediment, and to avoid disturbing the sediment surface. The sediment tray was left in the seawater table for 20 min, giving active clams adequate time to burrow below the sediment surface (based on our trial burial observations). After $20 \mathrm{~min}$, any unburied clams were recorded, and the tray was moved from the seawater table into a recessed section of the flume, in a flow speed of less than $2 \mathrm{~cm} \mathrm{~s}^{-1}$. Unburied clams were washed out of the array during this process. Then the treatment flow speed was established, and the vertical velocity profile started. Forty min after the treatment flow was established, the flow speed was reduced to less than $2 \mathrm{~cm} \mathrm{~s}^{-1}$, the maximum depth of sediment erosion was recorded, and the tray removed from the flume. The sediment was sieved through a $500 \mu \mathrm{m}$ sieve, and the clams were counted under a dissecting microscope. The cultured clams were easily distinguished from wild juveniles collected with the sediment, as the latter had been killed without preservative and were gaping. A new set of clams was used for each flume run.

For the snail treatments, 40 snails were placed on the sediment immediately following the placement of the clams, and allowed to move about and burrow. This density of snails was representative of the dense snail aggregations (1000 $\mathrm{m}^{-2}$ and higher) quantified at field sites in Barnstable Harbor. An acrylic fence prevented the snails from moving off the sediment during the $20 \mathrm{~min}$ they were in the seawater table. The fence was removed before the sediment tray was put into the flume and the snails were allowed to move about freely. Most of the snails moved upstream during the 40 min flume run, and the number remaining in the sediment tray at the end of the run ranged from 1 to 16 .

Preliminary trial runs were conducted for each clam size to estimate the critical erosion velocities of unburied clams and select a minimum velocity for subsequent experiments. Twenty dead clams were placed on top of the sediment with the flume running at less than $2 \mathrm{~cm} \mathrm{~s}^{-1}$. Clams were killed in ethanol which has no effect on their fall velocity (Roegner et al. 1995) or shape, and presumably no effect on their critical erosion velocity. After the clams were placed in the flume, the flow speed was raised slowly until 10 of the 20 clams were eroded off the sediment tray. At this speed, a velocity profile was recorded as described above. The shear velocity at which $50 \%$ of the clams on the surface of the sediment was eroded appeared to be slightly greater for the small than the large clams $(u .=$ $1.0 \mathrm{~cm} \mathrm{~s}^{-1}$ and $0.8 \mathrm{~cm} \mathrm{~s}^{-1}$, respectively). This difference, however, was no greater than the variation among replicate runs (conducted for a separate study) of a single clam size. Based on these measurements, a shear velocity of $1.0 \mathrm{~cm} \mathrm{~s}^{-1}$ was selected as the minimum flow for flume experiments of the smaller clams. Bulk transport of the sediment did not occur at this shear velocity, so suspension of buried clams would occur only if the clams actively moved to the sediment surface.

To determine whether snails lowered the critical erosion velocity of juvenile clams (low velocity treatment), and whether they increased clam suspension during sediment transport (high velocity treatment) we conducted 12 flume runs for each clam size-group. These 12 runs consisted of 3 replicate runs for each of 2 snail treatments (with and without snails) and each of 2 shear velocities. At the lower shear velocity, bulk sediment transport did not occur, and only clams exposed to the surface were susceptible to suspension. At the higher shear velocity, bulk sediment transport did occur, making buried clams also susceptible to suspension. Greater shear velocities were used for the larger clams because of their presumed deeper burial position. All shear velocities were within the range of those estimated from current velocities recorded through a tidal cycle by Ayers (1959) over a Barnstable Harbor tidal flat.

Over each multi-day experiment, the clam cultures experienced unpredictable mortality. Because of the uncertainty whether sufficient individuals would be available for both the low and high velocity treatments, the sequence of shear velocity treatments was not randomized (i.e. all the high-velocity runs were done first). However, the sequence of snail-treatment runs was randomized over each experiment. Two hundred clams were used in each flume run except for the lowvelocity treatment of the experiment on big clams, for which 100 individuals were used per run (Table 1). An additional complication to the studies was the quality of the sediment. A majority of the clams burrowed during the 20 min period in the seawater table, except on the final day of the experiment on small clams, when the numbers of unburied clams was greater in the slow-flow runs (which were at the end of the series) than in the faster flows. Because of the potential interaction between sediment quality/clam vitality and the sequence of velocity runs, differences attributed to velocity are interpreted cautiously (see 'Results').

The proportion of clams retained in the flume runs (excluding unburied individuals) was arcsin transformed and analyzed for each clam size in a separate 2-way ANOVA (Systat version 6.1) with snail presence (2 levels: snail and no-snail) and velocity (2 levels: fast and slow) as fixed factors.

Field experiments. To test for the effect of snails on juvenile clams in the field (Thatch Island site), a set of 
Table 1. Clam retention in sediment exposed to snails during flume experiments. Mean velocity at $8 \mathrm{~cm}$ above the bottom ( $U_{8}$ ) and shear velocity (u.) were measured with a laser doppler velocimeter. A known number of clams was seeded into the sediment; the number not buried and the number retained in the sediment at the end of a 40 min flume run were recorded. Maximum sediment erosion was measured from sediment surface. " Not recorded

\begin{tabular}{|c|c|c|c|c|c|c|c|c|}
\hline Clam size & $\begin{array}{c}\text { Flow } \\
\text { category }\end{array}$ & $\begin{array}{l}\text { Snail } \\
\text { treatment }\end{array}$ & $\begin{array}{c}U_{8} \\
\left(\mathrm{crn} \mathrm{s}^{-1}\right)\end{array}$ & $\begin{array}{c}u . \\
\left(\mathrm{cm} \mathrm{s}^{-1}\right)\end{array}$ & $\begin{array}{l}\text { Clams } \\
\text { seeded }\end{array}$ & $\begin{array}{c}\text { Clams } \\
\text { unburied }\end{array}$ & $\begin{array}{l}\text { Clams } \\
\text { retained }\end{array}$ & $\begin{array}{l}\text { Erosion } \\
\text { (cm) }\end{array}$ \\
\hline \multirow{11}{*}{$\begin{array}{l}\text { Mid-season } \\
(1.8 \mathrm{~mm})\end{array}$} & \multirow[t]{6}{*}{ Fast } & \multirow[t]{3}{*}{ No snail } & 32.7 & 1.4 & 200 & 0 & 118 & 0.0 \\
\hline & & & 33.6 & 1.4 & 200 & 13 & 107 & 0.0 \\
\hline & & & 31.9 & 1.4 & 200 & 25 & 128 & 0.2 \\
\hline & & \multirow[t]{3}{*}{ Snail } & 32.1 & 1.5 & 200 & 30 & 47 & 0.2 \\
\hline & & & • & . & 200 & 9 & 47 & 0.2 \\
\hline & & & - & $\cdot$ & 200 & 40 & 43 & 0.2 \\
\hline & \multirow[t]{5}{*}{ Slow } & No snail & 21.7 & 0.9 & 200 & 15 & 154 & 0.0 \\
\hline & & & 21.7 & 1.0 & 200 & 20 & 174 & 0.0 \\
\hline & & Snail & 21.6 & 1.0 & 200 & 40 & 72 & 0.2 \\
\hline & & & 22.9 & 1.0 & 200 & 30 & 115 & 0.0 \\
\hline & & & 21.9 & 1.0 & 200 & 30 & 83 & 0.1 \\
\hline \multirow{12}{*}{$\begin{array}{l}\text { Late-season } \\
(2.3 \mathrm{~mm})\end{array}$} & \multirow[t]{6}{*}{ Fast } & No snail & 47.5 & 2.1 & 200 & 0 & 150 & $\cdot$ \\
\hline & & & 49.0 & 2.0 & 200 & 12 & 95 & 1.0 \\
\hline & & & 46.9 & 2.0 & 200 & 0 & 118 & 0.8 \\
\hline & & Snail & 47.5 & 1.9 & 200 & 0 & 118 & $\cdot$ \\
\hline & & & 46.3 & 1.9 & 200 & 0 & 5 & 2.0 \\
\hline & & & 46.0 & 1.9 & 200 & 0 & 12 & 2.0 \\
\hline & \multirow[t]{6}{*}{ Slow } & No Snail & 28.8 & 1.3 & 100 & 2 & 86 & - \\
\hline & & & 29.7 & 1.3 & 100 & 4 & 93 & 0.0 \\
\hline & & & $\cdot$ & $\cdot$ & 100 & 0 & 87 & 0.0 \\
\hline & & Snail & 27.5 & 1.2 & 100 & 0 & 38 & 0.4 \\
\hline & & & 30.0 & 1.3 & 100 & 0 & 82 & 0.5 \\
\hline & & & 27.9 & 1.2 & 100 & 20 & 39 & 0.1 \\
\hline
\end{tabular}

10 cages, 5 with snail-access holes and 5 without, were placed on plots of sediment. Snails were removed from all plots at the start of the experiment and were allowed to migrate back only onto plots with access holes. Each cage frame was $0.33 \mathrm{~m}$ tall and covered a $1 \mathrm{~m}^{2}$ area plot. Frames were constructed of $1.25 \mathrm{~cm}$ diameter PVC tubing, and covered on the top and sides with plastic mesh netting (1.25 cm mesh size, supplied by Internet Co., MN). The mesh was secured to the frame with cable ties. Cages that allowed entry of snails had 4 access holes on each side and 20 access holes on the top. Each access hole was approximately $2.5 \mathrm{~cm}$ in diameter, which was big enough to accommodate even the largest Ilyanassa obsoleta.

Plots were arranged in a 2 by 5 rectangular array, separated from each other by approximately 2 to $3 \mathrm{~m}$. This arrangement was dictated by the small size and elongated topography of the site, and ensured that all plots were at a similar tidal height and in a homogeneous sedimentary environment. Optimally, plots would have been placed further apart (at least $10 \mathrm{~m}$ ) to prevent hydrodynamic effects of the cage on its neighbors. However, because the snail treatments were randomized spatially, we did not anticipate that treatment effects would be confounded by cage wakes or other hydrodynamic artifacts.

Snails were removed from all plots and cages were buried approximately $3 \mathrm{~cm}$ into the sediment on all sides of the plot. Sediment under the cages was sampled with $6.5 \mathrm{~cm}$ diameter cores to a depth of $4 \mathrm{~cm}$ at the beginning of the experiment (July 15) and at intervals of 12,34 and 45 d. Five additional cores were collected in nearby ambient sediments to measure clam abundance in ambient sediments outside the cages. These nearby cores were taken $3 \mathrm{~d}$ before the experiment started (July 12; Day -3), and on Days 12, 34 and 45 as for the plots.

The initial core sampling was performed before cages were in place, but after all snails had been cleared from the plots. Three replicate cores were collected in each plot to establish within-plot variance of clam abundance. Subsequent samplings were done by cutting the mesh on one of the top corners of the cage and taking a single core near the center of the plot. The specific location of the sample within the plot was recorded and no location was sampled twice. After each sampling event, cages were refastened with thread and cable ties. Core samples were sieved onto a 
$180 \mu \mathrm{m}$ sieve in the field and preserved in $4 \%$ buffered formaldehyde in seawater.

In the laboratory, samples were stained overnight in Rose Bengal, sieved onto a $300 \mu \mathrm{m}$ sieve and juvenile Mya arenaria (0-year-class recruits) were counted under a dissecting microscope. Abundances of $M$. arenaria were compared between treatments (2 levels; snails vs no-snails) and among days (3 levels: Day 12 , Day 34 and Day 45) of the experiment using a 2-way analysis of variance (Systat version 6.1). Abundances on Day 0 were not included in that ANOVA, but were analyzed separately in a 1 -way ANOVA to determine whether initial mean abundances differed between the 2 snail treatments. Abundance of $M$. arenaria juveniles in the ambient sediments was compared among sampling days (4 levels: Day -3, Day 12, Day 34 and Day 45 of the experiment) with a 1 -way ANOVA

Wind velocities were recorded approximately $30 \mathrm{~km}$ from the field site at the Woods Hole Oceanographic Institution meteorological station in Woods Hole for the duration of the experiments. The measurements were used to document the timing of major wind events in the region.

\section{RESULTS}

\section{Flume experiments}

Three replicate runs were completed for all combinations of clam size, flow and snail treatments, with only one exception (Table 1). Flume flow velocities at $8 \mathrm{~cm}$ above bottom $\left(U_{8}\right)$ and shear velocities $\left(u_{*}\right)$ varied relatively little among the 6 replicate runs at each flow setting (Tables $1 \& 2$ ). In a few cases, velocities at a particular flume setting (i.e. pump speed and weir gap) were not recorded due to malfunctions in the data acquisition system. The final (no-snail) run of the slowflow treatment in the mid-season clam experiment was excluded because a large percentage of the clams did not burrow, possibly due to poor sediment quality.

Table 2. Mean alongstream velocity at $8 \mathrm{~cm}$ above flume bottom $\left(L_{8}\right)$ and mean shear velocity $\left(u_{*}\right)$ for fast and slow flow treatments used for mid-season and late-season clam experiments. Standard deviations in parentheses

\begin{tabular}{|lcccc|}
\hline $\begin{array}{lccc}\text { Clam } \\
\text { category }\end{array}$ & $\begin{array}{c}\text { Flow } \\
\text { category }\end{array}$ & $\begin{array}{c}U_{8} \\
\left(\mathrm{~cm} \mathrm{~s}^{-1}\right)\end{array}$ & $\begin{array}{c}u_{0} \\
\left(\mathrm{~cm} \mathrm{~s}^{-1}\right)\end{array}$ & $\mathrm{n}$ \\
\hline Mid-season & Fast & $32.6(0.8)$ & $1.4(0.05)$ & 4 \\
& Slow & $22.0(0.8)$ & $1.0(0.00)$ & 6 \\
Late-season & Fast & $47.2(1.1)$ & $2.0(0.10)$ & 6 \\
& Slow & $28.9(0.9)$ & $1.3(0.09)$ & 5 \\
\hline
\end{tabular}
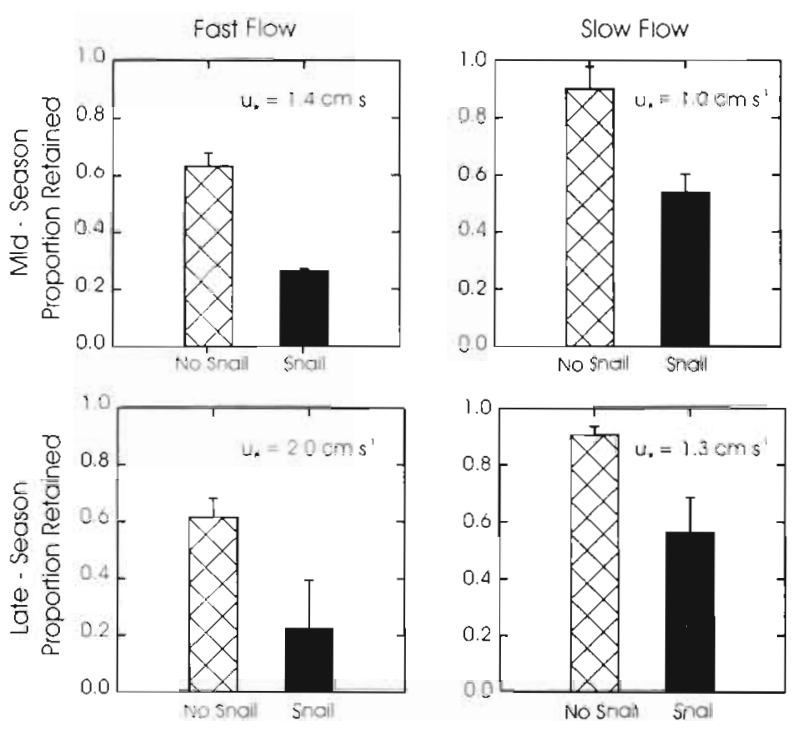

Fig. 1. Proportion of mid-season (1.8 mm) and late-season (2.3 $\mathrm{mm}$ ) Mya arenaria (mean and standard error; $\mathbf{n}=3$ ) retained in flume runs. Unburied clams were excluded from calculation of proportion retained. Snail treatment was exposed to disturbance by Ilyanassa obsoleta; No-snail treatment was left undisturbed. Shear velocity $u$. shown for each set of runs

Attempts to use the remaining clams to repeat the run on the following day were unsuccessful.

For both clam sizes, and for all shear velocities, the proportion of clams retained was significantly greater in the no-snail than the snail treatments (Fig. 1; Table 3), indicating that the snails enhanced clam suspension. Clam retention also was significantly greater in the slow-flow than fast-flow treatments. No significant interaction was detected between snail and flow effects. The flow effect appears to be valid, despite the fast-flow runs having been conducted prior to the slow-flow runs, because the result was opposite to what would have been expected from an artifact of clam vitality (i.e. clams in poor condition at the end of the experiments would be expected to burrow poorly and be more susceptible to suspension).

As expected, most (>90\%) of the clams in the slowflow treatments were not eroded from the sediments in the absence of snails (Fig. 1). This result was consistent for both the mid-and late-season clam sizes. At the shear velocities used $\left(1.0\right.$ and $\left.1.3 \mathrm{~cm} \mathrm{~s}^{-1}\right)$, individual sediment grains were observed to move, but bulk sediment transport (erosion of $1 \mathrm{~mm}$ or more from the sediment surface) did not occur. With the addition of snails, however, over $40 \%$ of the clams were suspended. Erosion of the sediment was increased (Table 1) and visual observations showed that once the clams were exposed to the sediment surface they were unable to burrow back down. This result indicates that 
Table 3. Two-way analyses of variance of the proportion of clams (arcsin transformed) retained within the sediment in flume experiments on mid-season $(1.8 \mathrm{~mm})$ and late-season $(2.3 \mathrm{~mm})$ clam sizes. Calculation of clams retained excluded individuals that had not burrowed

\begin{tabular}{|llcccrc|}
\hline Clam size & Source & Sum-of-squares & df & Mean-square & F-ratio \\
\hline Mid-season & Snail & 0.659 & 1 & 0.659 & 36.744 & 0.001 \\
& Speed & 0.392 & 1 & 0.392 & 21.869 & 0.002 \\
& Snail $\times$ Speed & 0.016 & 1 & 0.016 & 0.887 & 0.378 \\
& Error & 0.126 & 7 & 0.018 & 10.821 & 0.011 \\
Late-season & Snail & 0.690 & 1 & 0.690 & 0.704 & 0.018 \\
& Speed & 0.555 & 1 & 0.555 & 0.007 & 0.746 \\
& Snail $\times$ Speed & 0.007 & 1 & 0.064 & & \\
\hline
\end{tabular}

snails lower the shear velocity at which active, burrowing juvenile clams are suspended.

For both clam sizes, suspension in the fast-flow treatment without snails was similar to suspension in the slow-flow treatment with snails (Fig. 1), suggesting that the effect of snails in the field (at these densities) may be comparable to a substantial $\left(0.6\right.$ to $0.7 \mathrm{~cm} \mathrm{~s}^{-1}$ ) increase in boundary shear velocity. Bulk sediment transport occurred at the shear velocities used in the fast-flow treatments $\left(u_{.}=1.4\right.$ and $\left.2.0 \mathrm{~cm} \mathrm{~s}^{-1}\right)$.

As expected, the 2 different clam sizes were not equally susceptible to suspension. For example, in the absence of snails, the proportion of smaller (mid-season) clams retained at $u_{0}=1.4 \mathrm{~cm} \mathrm{~s}^{-1}$ was much lower than the proportion of larger (late-season) clams retained at $u_{0}=1.3 \mathrm{~cm} \mathrm{~s}^{-1}$, but similar to the proportion of larger clams retained at $u_{0}=2.0 \mathrm{~cm} \mathrm{~s}^{-1}$ (Fig. 1). This pattern of larger clams needing a higher shear velocity than smaller clams to suspend a specific proportion of individuals was consistent for all combinations of snail and flow treatments.

\section{Field experiments}

Abundance of Mya arenaria juveniles was significantly higher in the no-snail than the snail plots over the course of the $45 \mathrm{~d}$ field experiment (Fig. 2; Table 4). At the start of the experiment (Day 0), $M$. arenaria abundance was not significantly different between the plots intended for the no-snail cages and those intended for snail cages, but was significantly lower than abundances in ambient sediments collected $3 \mathrm{~d}$ before the initiation of the experiment (1-way ANOVA with post-hoc Bonferroni test; $\mathrm{df}_{\text {treat }}=2 ; \mathrm{df}_{\text {error }}=10_{i} F=$ $6.005 ; p<0.02$ ). This difference probably resulted from the disturbance caused by removing the snails from the experimental plots. High abundances in the ambient sediment persisted to Day 12 (Fig. 2), but became significantly lower on Days 34 and 45 (1-way ANOVA

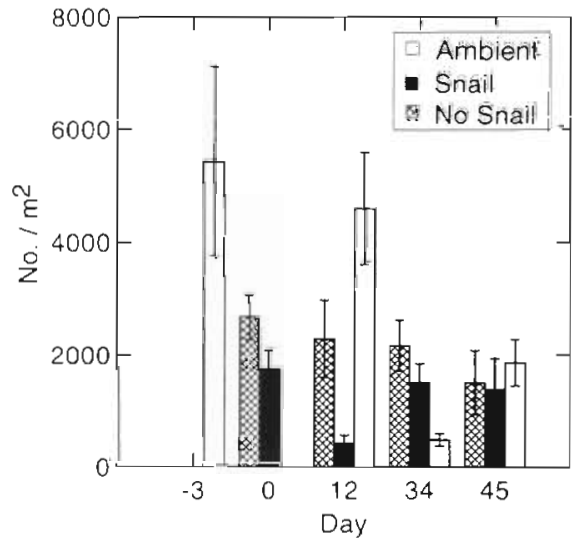

Fig. 2. Abundance of Mya arenaria in $6.5 \mathrm{~cm}$ diameter core samples collected in ambient sediments (Ambient), and under cages that permitted (Snail) or excluded (No Snail) immigration of Ilyanassa obsoleta. Values are means and standard errors of 5 samples. Ambient sediment samples were taken 3 d before experiment started (July 12, 1997). On Day 0 (July 15), samples were taken in cleared plots before cages were put in place. On Days 12,34 and 45, samples were taken under cages and in ambient sediment

Table 4. Two-way analysis of variance of abundance of juvenile clams in a field experiment. Snail exclusion experiment comprised 2 snail treatments (nets with and without access holes) and was sampled on $3 \mathrm{~d}(13,34$ and 45 d). Day 0 was excluded from analysis

\begin{tabular}{|lcrrrr|}
\hline Source & $\begin{array}{l}\text { Sum-of- } \\
\text { squares }\end{array}$ & df & $\begin{array}{c}\text { Mean- } \\
\text { square }\end{array}$ & F-ratio & $\mathrm{p}$ \\
\hline Snail & 64.533 & 1 & 64.533 & 4.297 & 0.049 \\
Day & 14.467 & 2 & 7.233 & 0.482 & 0.624 \\
Snail $\times$ Day & 44.067 & 2 & 22.033 & 1.467 & 0.251 \\
Error & 360.4 & 24 & 15.017 & & \\
\hline
\end{tabular}

with post-hoc Bonferroni test: $\mathrm{df}_{\text {day }}=3$; $\mathrm{df}_{\text {error }}=14 ; F=$ 9.205; $\mathrm{p}<0.001$ ) On Day 45, numbers of $M$. arenaria juveniles in ambient sediments were slightly higher 
than on Day 34, but their mean size (data not shown) was no smaller, as would have been expected for a lateseason recruitment event.

The cages operated as intended, with no Ilyanassa obsoleta invading the nosnail treatment (except in cases when wind events eroded underlying sediments and provided access), and many invading the snail treatment, in numbers comparable to their natural abundances. The cages should not have affected access of potential clam predators differentially between treatments; green crabs, moon snails and other infaunal species could easily burrow under the cages, and larger predators such as horseshoe crabs and birds were too large to get through the access holes. No substantial difference in the abundance of potential predators was noted between the 2 cage treatments or between the caged plots and ambient sediments.

The magnitude of the difference in Mya arenaria abundance between nosnail and snail treatments varied notably through the course of the experiment (Fig. 2), even though variance associated with sampling day alone and the interaction between snail and day were both non-significant (Table 4). Much of this variation corresponded with the unwanted invasion of snails into no-snail plots through pits eroded under the cages (these snails were removed and the pits refilled with sediment when detected). For instance, on Day 12, snails had been excluded successfully from all no-snail plots except one, which harbored a few individuals. Mean $M$. arenaria abundance in the no-snail plots was more than 5 times that in snail plots. On Day 34, snails had invaded 3 of the 5 no-snail plots (but in lower than natural densities), and the difference in $M$. arenaria abundance between the no-snail and snail plots was much reduced. On Day 45 , snails had invaded 4 of the no-snail plots (in near-natural densities), and $M$. arenaria abundance in the no-snail plots was only slightly higher than in the snail plots. The experiment was terminated on that day.

Wind records from the WHOI meteorology station provided evidence of 3 substantial storms that we suspect were responsible for the observed sediment scour. Summer winds over Barnstable Harbor are typically light and variable in the morning, increasing to a steady 2 to $3 \mathrm{~m} \mathrm{~s}^{-1}$ breeze from the southwest in the afternoon. In contrast, the wind events on August 13 and 15 (Days 29 and 31) were characterized by sus- tained gales of 5 to $6 \mathrm{~m} \mathrm{~s}^{-1}$ with strong gusts (Fig. 3). Because sediment transport on tidal flats can be greatly enhanced during such events, the scour observed in our experiments probably occurred on one or both of these dates. Thus, by Day 34, the snails would have had access to the no-snail plots for only a few days. The storm that began on August 20 (Day 36) was larger than any other during the experiment, and was characterized by sustained winds of $>10 \mathrm{~m} \mathrm{~s}^{-1}$. The snails probably gained entry to the no-snail plots at this time, and thus were present for most of the final interval

\section{DISCUSSION}

Our flume experiments suggest that in natural field conditions disturbance by the snail llyanassa obsoleta is likely to cause juveniles of Mya arenaria to be suspended in flows slower than those needed to suspend undisturbed clams. Thus, the presence of snails is expected to expand the range of flow environments in which juvenile clams are susceptible to transport. These studies also indicate that disturbance is likely to increase the magnitude of hydrodynamic transport of clams during sediment transport events except during very energetic events when all clam juveniles are suspended regardless of the presence of snails. The mech- 
anism of disturbance appears to be 2 -fold: the snails move laterally just below the sediment surface and expose clams to boundary shear stresses both by mixing them vertically and by causing the sediment above them to erode. Other behaviors by the clams that might affect resuspension, such as using a byssal thread to drift (as described for other species in a flume study by de Montaudouin 1997), were not observed.

Our flume results are consistent with previous observations (Roegner et al. 1995) that small Mya arenaria exposed on the sediment surface are more susceptible to suspension than those buried in sediment. However, in our fastest flow $\left(u .=2.0 \mathrm{~cm} \mathrm{~s}^{-1}\right)$ greater than $60 \%$ of the undisturbed (no-snail) clams remained in the sediment, whereas virtually all the clams were suspended in the fastest flow $\left(u_{0}=1.75 \mathrm{~cm} \mathrm{~s}^{-1}\right)$ of Roegner et al. (1995). We think this difference can be explained by the larger size of our recruits $(1.8$ to $2.3 \mathrm{~mm}$ vs 0.24 to $0.29 \mathrm{~mm}$ ), and possibly by the longer time allowed for burrowing (20 vs $5 \mathrm{~min}$ ). Roegner et al. (1995) calculated that for clams intermediate in size to the 2 groups used in the present study, a single suspension event could lead to a 2 to $10 \mathrm{~m}$ transport distance, depending upon the suspension height. With multiple suspensions, clams could easily be transported much greater distances. If increased suspension of clams due to the presence of Ilyanassa obsoleta leads to the increased translocation of clams in the field, then this should lead to local decreases in clam abundance where I. obsoleta is present.

The effect of Ilyanassa obsoleta on suspension of Mya arenaria in our flume experiments is similar in many aspects to the effects of the snail Hydrobia ulvae on suspension of benthic diatoms and bacteria observed in flume studies by Blanchard et al. (1997). Hydrobia ulvae is smaller ( 4 to $6 \mathrm{~mm}$ in length) than $I$. obsoleta (12 to $20 \mathrm{~mm}$ ), but it also disrupts the sediment by moving laterally below the sediment surface. Using shear velocities similar to ours, Blanchard et al. (1997) showed that suspension of both bacteria and benthic diatoms was enhanced by the presence of $H$. ulvae. They attribute some of this effect to attachment of the microbiota to the snails' easily eroded mucus trail; these surface agglomerates were seen to become suspended at lower shear velocities than the free sediment. Our flume observations suggest this process may not be an important factor in the $I$. obsoleta- $M$. arenaria interaction because the snails usually moved below the sediment surface in the presence of flow, and we detected no suspension of mucus-sediment agglomerates during detailed visual observations of snail and clam behavior.

Our field observations on Days 12 and 34 (for which storm disturbance was minimal) support the flume prediction that disturbance by Ilyanassa obsoleta en- hances suspension of Mya arenaria juveniles and leads to a local decrease in clam abundance. The snail effect was not apparent on Day 45 because a large storm on Day 36 had allowed snails access to the no-snail cages. Other studies have demonstrated that the disturbance by $I$. obsoleta can lead to large changes in the abundance of Hydrobia totteni (Levinton et al, 1985) and Microdeutopus gryllotalpa (DeWitt \& Levinton 1985). In each of these studies the response of the disturbed species was to emigrate actively from the habitat containing $I$. obsoleta. In contrast, the mechanism of disturbance in our study was by the snail increasing the susceptibility of juvenile clams to passive erosion. We suggest that this mechanism also may have played a role in the reduction of nematodes (Nichols \& Robertson 1979) and other taxa (Hunt et al. 1987) observed in previous field manipulations of $I$. obsoleta.

Alternative explanations for the snail effect observed in our field experiments are possible, but we consider most of them unlikely. One possibility is that differences in the abundance of Mya arenaria were due to the horizontal migration of the juvenile clams out of the snail plots. Zobrist \& Coull (1992) and Ahn et al. (1993) documented very little horizontal emigration in the hard shell clam Mercenaria mercenaria in response to disturbances. The degree to which $M$. arenaria is capable of moving horizontally through the sediment remains to be tested, but it is unlikely to be sufficiently directed to result in concerted migration on the scale of meters. Active vertical migration, however, could change the susceptibility of juveniles to suspension and may have played an undetected role in our results. A third possibility is that other organisms were able to enter the cage through the access holes provided for snails. However, all macro-invertebrates observed in the snail plots (exclusive of the snails) were also observed in the no-snail plots. Lastly, it could be argued that the strong effect of snail disturbance might not occur in natural habitats in the absence of cages. We consider this possibility unlikely because the effect was demonstrated, without cages, in the flume. We investigated several alternative methods for excluding snails in the field, but none worked as well as the cages.

We expect the susceptibility of Mya arenaria juveniles to suspension to decrease as they grow because they will become heavier and capable of deeper burrowing. When they initially settle, and can be suspended in shear velocities as low as $1.0 \mathrm{~cm} \mathrm{~s}^{-1}$ (Roegner et al. 1995), they are likely to be transported in routine tidal flows (as measured in Ayers 1959). At some size, they will no longer be suspended by tidal flows, but may be transported by energetic wind events. Also, at some size, they will burrow below the depth disturbed by the snail llyanassa obsoleta 
(roughly 1 to $2 \mathrm{~cm}$ ), and will attain a refuge from that disturbance. Investigation of these critical sizes is worth further research, as it will provide information about the relative influences of hydrodynamic transport and biological disturbance on $M$. arenaria juveniles as they grow through the first year

The variance of juvenile Mya arenaria abundance over time was different in the caged plots than in ambient sediments. The abundance of $M$. arenaria in ambient sediments dramatically decreased between Days 12 and 34, whereas abundances in the plots did not vary significantly over the course of the experiment. This pattern indicates that clams either were suspended less or deposited more inside the cages than outside. Mesh netting similar to that in our cages is used by many shellfish managers and aquaculturists to enhance recruitment and survival of bivalve spat (Marcotti \& Leavitt 1997). The function of these nets is presumed to be exclusion of predators, but they are rarely effective at excluding anything but birds and horseshoe crabs. Our results suggest that the true function of these nets may be to reduce suspension and/or enhance deposition of juvenile $M$. arenaria, and thereby increase the local abundance of clams. The disturbance of clearing the snails and placing cages for the field manipulations, however, initially caused a decrease in the abundance of $M$. arenaria. Although this disturbance was minimized as much as possible, it was apparently enough to suspend clams and cause them to be transported away from the plots. If disturbance of the sediment causes significant suspension of juvenile clams, care is needed to minimize sediment disturbance in settlement areas of $M$. arenaria, for long term sustainability of managed populations. Other researchers have shown that adult $M$. arenaria populations can be affected by disturbance, such as by harvesting of the lugworm Arenicola marina (Beukema 1982). A decrease in infaunal species abundance and diversity is considered to be a common consequence of the disturbance caused by shellfishing (e.g. Brown \& Wilson 1997).

llyanassa obsoleta is likely to play an important role in determining the adult distributions of Mya arenaria because snails can increase the suspension of mid and late season clams during wind events, and potentially can suspend clams even in tidal currents. This process may operate on scales of a few meters, by moving juveniles to different tidal heights. Or it may operate on scales of kilometers, possibly transporting juveniles out of an entire habitat during an ebb-tide sediment transport event. Not enough is known about the costs and benefits of postlarval resuspension to speculate upon whether or not it may be advantageous to the clams. Potential advantages to resuspension include transport to a more suitable habitat. However, resus- pension may expose clams to increased risk of predation, as well as to possible transport into a less hospitable area

Acknowledgements. We are grateful to Tom Marcotti and Kris Clark for their tireless help in the field and to Doug Kalweit and the Barnstable Department of Natural Resources staff for enthusiasm and use of facilities. Dale Leavitt helped inspire this project and was instrumental in getting the field component organized. Beals Island Shellfish Hatchery and Mook Sea Farm provided clams and advice. We thank Lara Gulmann, Heather Hunt, Anna Metaxas and 3 anonymous reviewers for their helpful suggestions on the manuscript. Support was provided by Sea Grant proposal NA86RG0075, with matching support from the Town of Barnstable Department of Natural Resources and the Rinehart Coastal Research Center, and to R.D. by a Woods Hole Oceanographic Institution Summer Fellowship. This is Woods Hole Oceanographic Institution contribution number 9828

\section{LITERATURE CITED}

Ahn IY, Lopez G, Malouf R (1993) Effects of the gem clam Gemma gemma on early post-settlement enigration, growth and survival of the hard clam Mercenaria mercenaria. Mar Ecol Prog Ser 99:61-70

Armonies $W$ (1996) Changes in distribution patterns of 0 group bivalves in the Wadden Sea: byssus drifting releases juveniles from the constraints of hydrography. $J$ Sea Res 35:323-334

Ayers JC (1959) The hydrography of Barnstable harbor, Massachusetts. Limnol Oceanogr 4:448-462

Beukema JJ (1982) Annual variation in reproductive success and biomass of the major macrozoobenthic species living in a tidal flat area of the Wadden Sea. Neth J Sea Res 15 $391-405$

Beukema JJ, de Vlas J (1989) Tidal-current transport of thread-drifting postlarval juveniles of the bivalve Macoma balthica from the Wadden Sea to the North Sea. Mar Ecol Prog Ser 52:193-200

Blanchard G, Sauriau PG, Cariou-Le Gall V, Gouleau D, Garet MJ, Olivier F (1997) Kinetics of tidal resuspension of microbiota: testing the effects of sediment cohesiveness and bioturbation using flume experiments. Mar Ecol Prog Ser 151:17-25

Brown $B$, Wilson WH (1997) The role of commercial digging of mudflats as an agent for change of infaunal intertidal populations. J Exp Mar Biol Ecol 218:49-61

Butman CA (1987) Larval settlement of soft-sediment invertebrates: the spatial scales of pattern explained by active habitat selection and the emerging role of hydrodynamics. Oceanogr Mar Biol Annu Rev 25:113-165

Butman CA, Chapman RJ (1989) The 17 -meter flume at the Coastal Research Laboratory. Part I. Description and user's manual. Woods Hole Oceanog Instit Tech Rep 89-10:1-31

Commito JA, Thrush SF, Pridmore RD, Hewitt JE, Cummings VJ (1995) Dispersal dynamics in a wind-driven benthic system. Limnol Oceanogr 40:1513-1518

de Montaudouin X (1997) Potential of bivalves' secondary settlement differs with species: a comparison between cockle (Cerastoderma edule) and clam (Ruditapes philippinarum) juvenile resuspension. Mar Biol 128:639-648

DeWitt T, Levinton J (1985) Disturbance, emigration, and refugia: how the mud snail, Ilyanassa obsoleta (Say), affects the habitat distribution of an epifaunal amphipod, 
Microdeutopus gryllotalpa (Costa). J Exp Mar Biol Ecol 92 : $97-113$

Eckman JE (1990) A model of passive settlement by planktonic larvae onto bottoms of differing roughness. Limnol Oceanogr 35:887-901

Emerson CW, Grant J (1991) The control of soft-shell clam (Mya arenaria) recruitment on intertidal sandflats by bedload sediment transport. Limnol Oceanogr 36:1288-1300

Fegley S (1987) Experimental variation of near-bottom current speeds and its effects on depth distribution of sandliving meiofauna. Mar Biol 95:183-191

Feller R (1984) Dietary immunoassay of Iyanassa obsoleta, the eastern mud snail. Biol Bull 166:96-102

Hunt J, Ambrose WJ, Peterson C (1987) Effects of the gastropod, Ilyanassa obsoleta (Say), and the bivalve, Mercenaria mercenaria (L.), on larval settlement and juvenile recruitment of infauna. J Exp Mar Biol Ecol 108:229-240

Jumars PA, Nowell ARM (1984) Fluid and sediment dynamic effects on marine benthic community structure. Am Zool $24: 45-55$

Levinton J, Stewart S, Dewitt $T$ (1985) Field and laboratory experiments on interference between Hydrobia totteni and Ilyanassa obsoleta (Gastropoda) and its possible relation to seasonal shifts in vertical mudflat zonation. Mar Ecol Prog Ser 22:53-58

Marcotti T, Leavitt DF (1997) The Barnstable Harbor Shellfish Recruitment Enhancement Project (BHSREP), a final report. Report to the Town of Barnstable, MA

Möller P, Rosenberg R (1983) Recruitment, abundance and production of Mya arenaria and Cardium edule in marine shallow waters, Western Sweden. Ophelia 22:33-55

Newell CR, Hidu H (1986) Species profiles: life histories and environmental requirements of coastal fishes and inverte-

Editorial responsibility: Joseph Pawlik (Contributing Editor), Wilmington, North Carolina, USA brates (North Atlantic) - softshell clam. US Fish Wildl Serv Biol Rep 82:17

Nichols JA, Robertson JR (1979) Field evidence that the eastern mud snail, llyanassa obsoleta, influences nematode community structure. Nautilus 93:44-46

Palmer MA (1984) Invertebrate drift: behavioral experiments with intertidal meiobenthos. Mar Behav Physiol 10:235-253

Palmer MA (1988) Dispersal of marine meiofauna: a review and conceptual model explaining passive transport and active emergence with implications for recruitment. Mar Ecol Prog Ser 48:81-91

Peterson C (1985) Patterns of lagoonal bivalve mortality after heavy sedimentation and their paleoecological significance. Paleobiology 11:139-153

Rodriguez SR, Ojeda FP, Inestrosa NC (1993) Settlement of benthic marine invertebrates. Mar Ecol Prog Ser 97:193-207

Roegner $C$, André $C$, Lindegarth $M$, Eckman JE, Grant J (1995) Transport of recently settled soft-shell clams (MYa arenaria L.) in laboratory flume flow. J Exp Mar Biol Ecol $187: 13-26$

Sigurdsson JB, Titman CW, Davies PA (1976) The dispersal of young post-larval bivalve molluscs by byssus threads. Nature 262:386-387

Trowbridge JH, Geyer WR, Butman CA, Chapman RJ (1989) The 17-meter flume at the Coastal Research Laboratory. Part II: flow characteristics. Woods Hole Oceanogr Instit Tech Rep 89-11:1-37

Zobrist E, Coull B (1992) Meiobenthic interactions with macrobenthic larvae and juveniles: an experimental assessment of the meiofaunal bottleneck. Mar Ecol Prog Ser 88:1-8

Zwarts L, Wanink J (1989) Siphon size and burying depth in deposit- and suspension-feeding benthic bivalves. Mar Biol 100:227-240

Submitted: September 19, 1998; Accepted: December 11, 1998 Proofs received from author(s): April 6, 1999 